Северин В. Д., Северин Н. В.

\title{
ФІЛОСОФСЬКО-КУЛЬТУРОЛОГІЧНИЙ ВИМІР ВИСТАВКОВОЇ ДІЯЛЬНОСТІ В КОМУНІКАТИВНОМУ ПРОСТОРІ СУСПІЛЬСТВА
}

У статті досліджено концепт виставкового дизайну як особливого виду художньопроектної діяльності, його роль та функиії в сучасній проектній культурі Украӥни. Виставковий дизайн XXI cm. характеризується використанням інновачійних технологій, щуо сприяє розкриттю головної ідеї експозиції.

Ключові слова: виставковий дизайн, експозиція, виставка, інноващійні технологї.

The article considers the research of the exhibition design problem in the creation of the modern exhibition display. The concept of exhibition design is defined, as well as its role and functions in information communication context of modern design culture all over the world. At the current stage of exhibition activities development, exhibition design is characterized by introduction of interaction, creative, multimedia design and innovative technologies.

Keywords: exhibition design, exposition, display, innovative technologies.

В статье исследован концепт выставочного дизайна как особенного вида художественно-проектной деятельности, его роль и функции в современной проектной культуре Украины. Выставочный дизайн ХХІв. характеризуется использованием инновационных технологий, что способствует раскрытию главной идеи экспозиции.

Ключевые слова: выставочный дизайн, экспозиция, выставка, инновационные технологии.

Постановка проблеми. Виставковий дизайн становить багатогранне явище сучасної культури. Виставки відображають матеріальну й духовну діяльність людини, політичні, економічні, соціальні й науково-технічні умови цієї діяльності, сприяють руху до лідерства, демонструють міць держави. Становлячи раціонально організований комплекс ідейних, смислових, естетичних і матеріальних компонентів, виставка концентрує в собі багато актуальних явищ мистецтва й культури, беручи участь у формуванні й розвитку загальнолюдських цінностей суспільства. Завдяки репрезентативності як найбільш ефективному способу передання інформації виставка апелює до надзвичайно широкого спектру понять і асоціацій у найрізноманітніших сферах гуманітарної галузі знання.

Актуальність. Виставкова діяльність в Україні, як і в інших країнах, виконує важливу роль і набуває винятково актуального значення. Це пояснюється тим, що виставки як фактор науково-технічного й культурного прогресу в сучасних умовах сприяють підвищенню ефективності та якості виробництва, розвитку економічних зв'язків і міжнародного співробітництва у вирішенні комплексних проблем. Вимоги сучасності, зумовлені прагненням до європейського стандарту як норми, стимулюють розвиток виставкової бази, модернізацію наявних виставкових площ і створення нових, придбання нових експонатів, що привертають широкий громадський інтерес, 
оскільки демонстрація промислової продукції й предметів мистецтва відображає рівень економіки й культури країни. Виставковий дизайн сприяє образному прочитуванню історії й сучасності, демонструючи за допомогою засобів експозиції досягнення в галузях науки, техніки, культури, мистецтва, тому потреба його всебічного дослідження в Україні періоду кінця XX - початку XXI ст. є актуальною.

Аналіз досліджень і публікацій показує, що вивченню проблеми виставкового дизайну в українському мистецтвознавстві приділена недостатня увага. Основними дослідниками виставкового дизайну в Росії є російські вчені Р.Р. Клікс, В.М. Шпаков, В.В. Литвинов, В.Р. Аронов, В.Л. Глазичев, В.П. Борисов, Д.Б. Дондурей, С.Б. Базазьянц, Л.Є. Стровський, Є.А. Розенблюм та ін. Багато робіт цих авторів уже застаріли, оскільки були видані у 70-90-х рр. ХХ ст. і не відображають інноваційних технологій, матеріалів, особливостей соціально-культурного й науково-технічного розвитку сьогодення. Гідної уваги серед робіт із дизайну виставок заслуговують сучасні дослідження американських дизайнерів-практиків Я. Лоренца, Л. Сколніка, К. Бергера.

В українському мистецтвознавстві відомі дослідження В. Даниленка, присвячені розвитку дизайну в Україні й Центрально-Східній Європі. Є окремі статті з вивчення в Україні дизайнерської діяльності (В. Срмілов, В. Сльков, О. Бойчук). Сучасні розроблення висвітлюють різні напрямки дослідження проблеми дизайну в Україні у XX ст. (Л. Соколюк, Н. Трегуб, І. Грицюк, В. Сидоренко та ін.). Однак проблема виставкового дизайну $є$ актуальним напрямком у сучасному мистецтвознавстві й вимагає більш глибокої уваги, оскільки останнім часом вплив виставкового дизайну у світі мистецтва, дизайну й комунікації помітно зріс. Тож метою статті є визначення концепту виставкового дизайну як особливого виду художньо-проектної діяльності, його ролі та функцій в інформаційно-комунікативному просторі сучасної проектної культури України.

Виклад основного матеріалу. Дослідники проблем дизайну стверджують, що на певному етапі люди почали використовувати предмети й навколишнє середовище як інструменти для задоволення інстинктивного імпульсу відкривати, підкреслювати, обожнювати, продавати й інтерпретувати елементи власного досвіду. Подібне «комунікаційне середовище» можна розглядати як творчу сферу, яка набуває все більшого визнання, - виставковий дизайн.

Місце й час зародження виставкового дизайну визначити досить складно, оскільки це явище залежить від внутрішніх потреб людини, воно може одночасно з'являтися в різних культурах, а розвиватися й проявляти себе по-різному. Очевидно, що, починаючи 31851 р., за умов технічного прогресу, «входження елементів естетики у виробництво поступово охоплює всі його сфери, зокрема й такі, як виготовлення автомобілів, радіоприймачів і навіть інструментів та станків» [1, с. 112]. У промисловій галузі відбувається міцне поєднання утилітарного й естетичного начал. Дати визначення виставкового дизайну теж складно у зв'язку з тим, що такі дисципліни постійно розвиваються й важко відстежити їх суть. Дослідники вважають, що для його характеристики необхідно враховувати спосіб комунікації, який у різний час означав різні речі, можливість «передачі інформації через середовище, що оточує 
людину» $[2$, с. 6]. Такий підхід робить можливим співпрацю як дизайнерів архітекторів, працівників музеїв, промислових дизайнерів або істориків, чия спільна робота створює незвичне поле для діяльності. У цей час існують окремі організації, що спеціалізуються в організації й створенні музейних експозицій, промислових ярмарків або історичних парків. Виставковий дизайн став процесом, що об'єднує всі ці сфери. У зв'язку з цим найбільш точним його визначенням у сучасній літературі вважають наступне: «Виставковий дизайн визначається як інтеграційний процес, який у різній мірі поєднує в собі архітектуру, дизайн інтер'єрів, графічний дизайн навколишнього середовища, друковану графіку, електронні та цифрові медіа, світло, звук, інтерактивні механізми та інші галузі дизайну» [2, с. 8].

Роль виставкового дизайну в організації сучасної експозиції полягає в тому, щоб у поєднанні з комунікаційним дизайном і дизайном приміщень створити середовище, яке забезпечує найбільш глибоке й повне передання інформації, сприяючи залученню аудиторії й посиленню інтенсивності розуміння. Виставковий дизайн постає своєрідним механізмом накопичення, збереження й трансляції сукупних знань із різних сфер соціокультурної дійсності, які візуалізуються, символізуються, оригінально впливаючи на інтелектуальний і емоційний стан людини як соціального суб'єкта. Він відіграє важливу роль у комунікативному просторі сучасного суспільства, сприяючи можливості обміну інформацією за допомогою створення певного знаково-символічного континууму, забезпечення міжособистісних контактів, задоволення потреб в умовах конкретно-історичного часу.

Серед функцій виставкового дизайну важливо підкреслити просвітницьку, яка розширює кругозір, формує світоглядну позицію, надаючи відвідувачам цінну й цікаву інформацію; пізнавальну, яка дозволяє розширити знаннєвий простір художньої діяльності; аксіологічну, що орієнтує на ціннісний потенціал, підкреслює художню цінність предмета; психологічну й естетичну функції, які впливають на чуттєво-емоційну сферу, викликаючи інтерес, пробуджуючи емоції, почуття; інтенсифікування й маніфестування, покликані акцентувати особливу увагу на предметі, підкреслити його унікальність, а також інші функції, що мають забезпечувати розв'язання головних завдань у презентації на виставці товарів. Дизайн виставки має розв'язувати важливі завдання: створення комфортного комунікаційного простору; посилення інтересу і сприйняття виставки; уніфікування методів і прийомів експонування; найбільш доступне забезпечення інформацією, створення умов для концентрації уваги, турбота про здоров'я глядачів (підбір освітлення, кольору, форми, розмірів, організації простору й т. п.), привертання уваги до пропонованого на виставці предмету або експонату; визначення його ролі в культурі; збереження культурної спадщини; організація вільного часу відвідувачів та ін. Успішне розв'язання всіх поставлених завдань сприяе привертанню уваги глядачів і покупців на виставках-продажах.

Розвиток виставкової діяльності в Україні отримав новий імпульс у роки незалежності. Вона зосереджена, головним чином, у Києві, Харкові, Львові, Дніпрі, Одесі. Можна виділити два етапи іiі розвитку: перший етап окреслюється 19922003 pp., другий - із 2003 р. і до сьогодні. Київ належить до найбільших виставкових 
центрів Центральної та Східної Свропи. Найбільш популярними зарекомендували себе такі виставкові заходи, як конгреси, форуми, фестивалі, конференції, симпозіуми, виставки, салони, ярмарки, аукціони.

Сучасні виставки, незалежно від різноманітності їх найменувань і організаційних форм, можна класифікувати таким чином:

- за географічним складом експонентів - на всесвітні, міжнародні, національні та локальні;

- за цілями проведення - на освітньо-пізнавальні: художні, науково-технічні, прикладного мистецтва, які не мають комерційних цілей; на торгові, які організовуються в основному з комерційною метою;

- за періодичністю проведення - на такі, які проводяться регулярно 3 певною періодичністю (щорічно, через рік, два Й т. п.); та нерегулярні, які організовуються у зв'язку з якоюсь ювілейною датою, окремими конгресами, з'їздами або з приводу інших подій; на постійно діючі, наприклад, виставка досягнень народного господарства м. Києва;

- за значенням для економіки міста, регіону, країни виставки поділяються на всеукраїнського, міжрегіонального, місцевого значення;

- за тематичним принципом або змістом представлених експонатів - на універсальні, де можна демонструвати продукцію й досягнення всіх галузей економіки, науки, техніки, культури; i на спеціалізовані, де демонструються продукція і досягнення однієї або декількох галузей промисловості, сільського господарства, науки, техніки, мистецтва [4, с. 187].

Організаторами виставок можуть бути музеї, корпорації, освітні установи, урядові структури. Безумовно, виставки використовують навколишнє середовище 3 метою комунікації й відрізняються за ії завданнями. Освітні виставки мають на меті інтерпретувати певну тему, предмет або історію, на той час як корпоративні виставки використовують інтерпретивні механізми як інструмент маркетингу.

Зупинимося на використанні сучасних інноваційних технологій у виставковому дизайні. Очевидно, що в сучасному постіндустріальному суспільстві значно зростає роль інформації. Теоретики інформаційного суспільства Д. Белл, Г. Шиллер, Ю. Хабермас, Е. Гідденс, Ж. Бодрійяр та ін. проголосили його як суспільство нового типу й відзначили великі зміни у сфері інформації та комунікації [5]. Виставковий дизайн набуває особливого значення завдяки своїй специфічній мові: нестандартним концептуальним розв'язкам і розробленням, різноманітним конструкціям, сучасним технічним засобам (формі, кольору, символіці, рекламі, мультимедійному супроводу) та іншим засобам вираження суті виставки, оскільки в ньому, як і в літературі та мистецтві, живуть і сучасність, і історична пам'ять людства про його минуле й майбутнє. Він консолідує, конкретизує, візуалізує інформацію і в демонстративному вигляді доносить їі до цільової аудиторії. Об’єднуючи в собі різні способи трансляції інформації, виставковий дизайн впливає на чуттєво-емоційну сферу відвідувача.

Характерною особливістю сучасної виставкової діяльності стала зміна іiі комунікаційних принципів, пов'язаних із тенденцією «відкритості», готовності вести активний діалог з глядачем [3]. У експозиційному мистецтві останнього десятиліття 
можна виділити основні напрямки, у руслі яких відбувається пошук експозиційних рішень і форм. Перший напрямок заснований на активній і відкритій побудові образу, здатного візуально втілювати найважливіші аспекти змісту. Його підгрунтям $\epsilon$ оригінальний концептуальний задум, а художня побудова $є$ візуальним пластичним утіленням адекватної художньої форми. Такі виставки допускають наявність концепції та сценарію й створюються в руслі авангардних форм сучасного станкового образотворчого мистецтва - поп-арту, інсталяції, із використанням спеціально виготовлених для конкретної експозиції творів експозиційного жанру.

Останнім часом чітко визначається другий напрямок, який наближається до традиційної «спокійної» й «логічної» побудови експозиції. У його розв'язках убачається тяжіння до верховенства експоната. Такий підхід характеризується функціональністю, ясністю композиційних побудов, лаконічністю засобів, високим рівнем якості. Цей напрямок тяжіє до світових аналогів і віддає перевагу чистому класичному дизайну та архітектурі на противагу арт-дизайну й сценографічному напрямку [3]. У таких експозиційних розв'язках важливу роль відіграють архітектурні й дизайнерські аспекти, функціональність систем обладнання, виконаних на основі новітніх технологій, якість і характер матеріалів, що використовуються в експозиції й виявляють свої не тільки технологічні та конструктивні особливості, але й семантичні. I тут важливу роль відіграє врахування потреб людей у вільний час поєднувати пізнання 3 розвагою, а для цього виставки мають використовувати видовищно-ігрові й інші методики організації поведінки й діяльності своїх відвідувачів. Виставки реалізують ідею зустрічі культури й цивілізації за допомогою світу предметів та ідей, допомагають людині пізнати себе, своє місце в культурі, світ у всьому його розмаїтті.

Сучасного відвідувача виставки можна назвати «новим культурним споживачем», орієнтованим як на отримання констатувальної інформації освітнього характеру, так і на отримання задоволення. Важливу роль у цьому відіграють інноваційні технології, особливо серед молоді, для якої екранна культура й електронні джерела інформації набагато більш звичні від книжкових. Використання аудіовізуальних засобів комунікації в експозиції й упровадження комп'ютерних технологій призвело до народження нової епохи у виставковому дизайні, де звук, світло, колір стають свого роду експонатами у віртуальному просторі.

На сучасному етапі розвитку виставкової діяльності у світовому масштабі виставковий дизайн характеризується широким застосуванням інтерактивного дизайну, інноваційних технологій, креативного й мультимедійного дизайну, використанням LED-технологій. Виставкова практика призвела до використання сучасних тенденцій формування простору виставкової експозиції за допомогою інтерактивного виставкового обладнання, трансформації обладнання, інноваційних матеріалів. Відбір та удосконалення засобів показу, створення економічних i мобільних модульних конструкцій стендів здатні втілити будь-який художній задум. Уніфіковані збірно-розбірні конструкції, висока культура їх виготовлення стали носіями позитивної інформації про експозицію. Разом вони створюють можливість пластично урізноманітнити архітектурний простір виставки та іiі предметне 
середовище, забезпечують особливу емоційну атмосферу, підкреслюють значимість і унікальність експонату.

У створенні науково-технічних виставок почав використовуватися новий принцип представлення експонатів - «підійди й доторкнися». Метою таких експозицій $\epsilon$ перетворення відвідувачів на дійових осіб. У цьому сенсі традиційний і новий тип експонування мають суттєві відмінності: традиційний спрямований на емпіричне переживання (звернений до життєвого досвіду відвідувача), а новий тип впливає на емоційне сприйняття, викликаючи безпосередню реакцію. Просторова організація таких експозицій також різна: у традиційній експозиції предмети розміщені у вітринах, на стінах і стелажах, що відокремлюють користувача від світу експонатів; в експозиції нового типу, навпаки, - увесь виставковий простір «заселений» рівною мірою як експонатами, так i публікою. Отже, новий тип експонування орієнтований на досягнення гармонії між предметом і його оточенням, на легкість сприйняття інформації відвідувачем.

Одним 3 найпомітніших процесів на межі XX-XXI ст. стало активне проникнення у виставковий простір аудіовізуальних, цифрових технологій. Це пояснюється швидким розвитком технічних засобів створення, презентації та збереження інформації. Сучасні цифрові технології сприяють розкриттю головної ідеї виставки, розширенню інформаційного поля експозиції. Оскільки комунікаційний аспект грунтується на різних рівнях участі цифрових технологій в інформаційному обміні між експозицією і відвідувачем виставки, серед них можна виділити такі типи:

- демонстраційний тип (експозиція-відвідувач: відбувається монолог, відвідувач «читає» експозицію);

- інтерактивний тип (експозиція-відвідувач: відбувається діалог, відвідувач взаємодіє з експозицією). У цілому виставковий дизайн зарубіжних країн надає можливість відвідувачеві бути учасником поданої експозиції.

Виставковий дизайн XXI ст. як у світі, так і в Україні став саме тією художньопроектною діяльністю, у якій спостерігається творчий, оригінальний підхід до використання цифрових технологій. Виставковий дизайн в Україні також характеризується новими тенденціями формування експозиційного простору, привнесенням сучасних технологій i контексту, які відповідають інноваційним потребам виставки. Підставою для нових експозиційних розв'язків стають якісні зміни стилістики в архітектурі й дизайні. Функціональність систем обладнання, виконаних на основі новітніх технологій, якість i характер матеріалів, що застосовуються в експозиції, проявляють свої технологічні, конструктивні й семантичні особливості. За допомогою сучасних виставкових центрів і заходів, що проводяться в умовах сучасної виставкової інфраструктури, найближчим часом стане можливим залучення в Україну значної кількості іноземних компаній та, як наслідок, інвестицій, а також нового глядача.

Висновки. В усі часи виставка мала на меті показати науково-технічні досягнення однієї країни чи різних країн в одній або кількох галузях виробництва, науки, техніки, мистецтва, оскільки в самій природі виставкового мистецтва закладено прагнення до всього нового й передового. І сьогодні виставкова діяльність 
демонструє досягнення ділових, наукових, творчих кіл країни. Виставковий дизайн дозволяє здійснювати за відносно низької собівартості експериментальну перевірку нових рішень, способів реалізації творчих задумів дизайнера. Взаємодіючи 3 архітектурним і природним оточенням, виставковий дизайн органічно доповнює його, вносячи в навколишнє середовище нові несподівані риси. В умовах незалежностій налагодження нових соціально-економічних відносин виставкова діяльність в Україні стає способом вираження рівня економіки й культури суспільства, показником конкурентоздатності товарів і послуг та могутнім засобом багатоцільової комунікації.

\section{Література:}

1. Даниленко В. Я. Дизайн : підручник. Харків : ХДАДМ, 2003.

2. Лорени Я., Сколник Л., Бергер К. Дизайн выставок : практическое руководство / пер. с англ. П. В. Кодолова. М. : АСТ : Астрель, 2008.

3. Майстровская M. T. Музейный образ - поиски и находки (экспозиционное искусство 90-х годов) / Музейная экспозиция. На пути к музею ХХІ века : сб. науч. тр. - М. : Минкульт РФ, РАН, РИК, 1997.

4. Стровский Л. Е. Основы выставочно-ярмарочной деятельности : учеб. пособ. для вузов : М. : ЮНИТИ-ДАНА, 2005.

5. Уебстер Ф. Теории информационного общества ; пер 3 англ. М. В. Арапова, Н. В. Малыхиной ; под. ред. Е. Л. Вартановой. М. : Аспект Пресс, 2004.

\section{Viktor Severyn, Nadiia Severyn}

\section{PHILOSOPHICAL AND CULTUROLOGICAL DIMENSION OF EXHIBITION ACTIVITY IN THE COMMUNICATIVE SPACE OF SOCIETY}

Exhibition activity in Ukraine is becoming important. Exhibitions as a factor of scientific, technical and cultural progress in modern conditions contribute improving the efficiency and quality of production, the development of economic relations and international cooperation. The object of the article is to define the concept of exhibition design as a particular aspect of art-design activity, its role and functions in the information and communication space of the modern design culture of Ukraine.

The problem of exhibition design is relevant in modern art history. Researchers suppose that at a certain stage people began to use objects and the environment as tools to satisfy an instinctive impulse to discover, emphasize, deify, sell and interpret elements of their own experience. Such «communication environment» considered as a creative sphere, or exhibition design. In the conditions of technical progress, the incorporation of elements of aesthetics into production gradually began to cover all production areas.

The role of exhibition design in the organization of modern exposition is to create, in combination with communication room design, an environment that would provide the most profound and complete transmission of information, help to attract the audience and increase the intensity of understanding. 
The functions of exhibition design are: educational, cognitive, axiological, psychological, aesthetic, communicative, etc.

Exhibition design in the $21^{\text {st }}$ century both in the world and in Ukraine is characterized by the use of innovative technologies, which contribute to the expansion of the information field of the exposition and the disclosure of its main idea.

Keywords: exhibition design, exposition, display, innovative technologies.

\section{Віктор Северин, Надія Северин}

\section{ФІЛОСОФСЬКО-КУЛЬТУРОЛОГІЧНИЙ ВИМІР ВИСТАВКОВОЇ ДІЯЛЬНОСТІ В КОМУНІКАТИВНОМУ ПРОСТОРІ СУПІЛЬСТВА}

Виставкова діяльність в Україні набуває важливого значення. Виставки як фактор науково-технічного й культурного прогресу в сучасних умовах сприяють підвищенню ефективності та якості виробництва, розвитку економічних зв'язків i міжнародної співпраці. Мета статті - визначення концепту виставкового дизайну як особливого виду художньо-проектної діяльності, його ролі та функцій в інформаційно-комунікативному просторі сучасної проектної культури України.

Проблема виставкового дизайну є актуальною в сучасному мистецтвознавстві. Дослідники вважають, що на певному етапі люди почали використовувати предмети й навколишнє середовище як інструменти для задоволення інстинктивного імпульсу відкривати, підкреслювати, обожнювати, продавати й інтерпретувати елементи власного досвіду. Таке «комунікаційне середовище» можна розглядати як творчу сферу, або виставковий дизайн. В умовах технічного прогресу входження елементів естетики у виробництво поступово стало охоплювати всі виробничі сфери.

Роль виставкового дизайну в організації сучасної експозиції полягає в тому, щоб у поєднанні 3 комунікаційним дизайном приміщень створити середовище, яке забезпечить найбільш глибоке й повне передання інформації, сприятиме залученню аудиторії й посиленню інтенсивності уваги.

Серед функцій виставкового дизайну слід підкреслити просвітницьку, пізнавальну, аксіологічну, психологічну, естетичну, комунікаційну та інші.

Виставковий дизайн XXI ст. як у світі, так і в Україні характеризується використанням інноваційних технологій, що сприяє розширенню інформаційного поля експозиції, розкриттю її головної ідеї.

Ключові слова: виставковий дизайн, експозиція, виставка, інноваційні технології.

Severyn Viktor - Candidate of Art History, associate professor, Department of Design of the Environment, Kharkiv State Academy of Design and Arts E-mail address: severiny84@gmail.com 
Северин Віктор Дмитрович - кандидат мистецтвознавства доцент кафедри «Дизайн середовища» Харківської державної академії дизайну i мистецтв, м. Харків.

e-mail: severiny84@gmail.com

Severyn Nadiia - Ph.D. in Philosophy, associate professor of the Department of Humanities of the Faculty of International Education, National Technical University "Kharkiv Polytechnic Institute".

E-mail address: severiny84@gmail.com

Северин Надія Василівна - кандидат філософських наук, доцент, доцент кафедри гуманітарних наук факультету міжнародної освіти Національного технічного університету «Харківський політехнічний інститут», м. Харків.

e-mail: severiny84@gmail.com

Надійшла до редакції 20.11.2018. Розглянута на редколегії 18.12.2018.

\section{Рецензенти:}

Доктор філософських наук, професор, професор кафедри філософії Харківського національного університету Повітряних Сил імені Івана Кожедуба Панфілов О.Ю.

Доктор філософських наук, професор, професор кафедри суспільно-гуманітарних дисциплін Харківського Національного університету будівництва та архітектури Проценко О.П. 